\title{
Bianca Ruhland
}

\author{
Those Who Wander
}

$\mathrm{T}$

unnels like these are always bad news. Dead in the middle of the forest, wind echoing out from the endless darkness. It's never a good idea to walk into a tunnel like this, you never know where you'll end up. There's too many books and movies out there to warn you not to, so you're an idiot if you do. Go in there and you'll end up trapped in another world with your parents turned into pigs and no yellow brick road to guide you. There'll probably be talking lions or some other sort of nonsense, just to waste your time. Even if you learn your moral lesson and return home, you certainly would have put your poor family through hell. Imagine trying to explain yourself to them. "Terribly sorry I've been gone so long, but I made friends with a flying boy and a Luck dragon." Adventures like that end in a padded cell, not a happily ever after. Not to mention you'd be horribly behind in your homework. You might even need to repeat a year, and most certainly you would have lost your job. There's no amount of rabbit holes in the world to help you out of the mess you'd be in.

It goes without saying that fantasy is a waste of time. I only wish that Mary-Alice saw things the same way.

Poor girl. She was always a dreamer. Growing up, the pretend games I'd play with her were fun enough. Problem was, she never grew out of them. The amount of times Aunt Ruth brought her over, and she'd have another fantasy table-top game tucked under her arm or a new video game to play were innumerable. I'd always cringe and glare at her when I saw the games, but the clouds around her head were too dense for her to notice. My afternoons with her would be spent pretending I was an 
elf, rolling dice to decide my fate or cramping up my thumbs playing her video games. Sometimes she'd stay the night and think it would be fun to marathon old fantasy movies that still used puppets.

So much study time wasted.

I'm sure when Mary-Alice had found the tunnel that day, her mind went in the same direction that mine had. Fantasy, magic worlds full of wonder and adventure. Of course, instead of cringing at such an inconvenience I'm sure her heart leapt at the thought. She probably would have wandered through, assuming it lead to exactly that. I wonder what it must have like to discover she was right.

It was two years ago that I was last here, standing in front of this tunnel.

I never liked studying in the woodlands behind our house. I'd have to stop my train of thought every two seconds just to flick a bug off me or look around my shoulder for anything that might kill me. Circumstances had given me no other choice that day. Our neighbours to the left decided that their house needed renovations at the same time our neighbours to the right decided they were partially deaf and needed their music up so high the bass shook the Richter scale. It's usually quieter in Mum's room. I would have gone in there, but I could hear her talking through the door. Aunt Ruth was on the phone. It had been two months since Mary-Alice had gone missing. Mum, Aunt Ruth and I had gone to the shops, but my cousin wanted to stay home. She had just gotten comfy on the couch and was two chapters away from finishing some book. When we got back she was gone, the book closed on the floor by the couch.

I could hear Mum and Aunt Ruth crying through the door. By that point, I remember Mum had finally given up trying to be optimistic. Every day she would wake up certain that Mary-Alice would come home. I had never wanted to give myself that kind of hope. I knew the facts, the more time that went by, the higher the chances were that she was dead.

I moved away from the door and made my way into the woodlands behind our home. Mum didn't like those woodlands very much. Neither did I. The police thought they might have played a role in Mary-Alice's disappearance and the sight of them just made us nervous. Thinking back, I can't describe it. I was just suddenly drawn to the hush of the trees and grass. It seemed the only place that day I could do any studying. Funny thing was, I forgot my schoolbooks. 
There were a few quiet spots around, though a rather nasty looking anthill occupied the first one and there were wasps hovering around in the second. The sky turned to lapis lazuli as twilight began to creep over the treetops. Crickets started to sing. I turned back for home.

That's when I found it.

At first I thought it was a cave, but the rocks that built the archway were too uniform. They made a perfect, even pattern. I stood there, stunned. How long had I lived with these woodlands behind my house? I had never seen this tunnel before. I took a closer look. It must have been there for a long time. The trees were bent and curved over and around the tunnel. Moss and weeds covered the cold, grey bricks like a bad rash. A veil of ivy hung down covering the entrance. I swept it away and looked into the hollow darkness. Through the thin ribbons of pale light amongst the ivy, I could make out the light patterns that traced the inner walls like a Book of Kells graffiti. It was so quiet, so hidden. What a perfect place to study. I remember instantly thinking that I needed to show Mary-Alice the next time she visited. I remember pausing for a moment, then turning my back on the tunnel and walking away. I must have remembered then that I had forgotten my books.

As I turned away, the corner of my eye caught something, a light at the end of the tunnel. When I walked away I heard something behind me. Footsteps. Not mine. I turned, the tunnel still visible through the trees. A hand reached through the veil of ivy.

"Hello?" came a voice.

My stomach knotted. My back slammed against a nearby tree. I pulled my arms in tight, hiding myself.

"Hello? Is someone out there?"

I can still remember how it felt when I recognised that voice. It was a numb disbelief, like that moment when you wake up and you can't tell your dreams from reality.

Mary-Alice was standing in the mouth of the tunnel. She looked around and found my face in amongst the trees.

"Maybel!" she called out, grinning like a Cheshire cat.

I rushed forward. Our bodies collided and our arms wrapped around one another.

"I missed you so much. Oh, Maybel!" she squealed. 
"Where have you been? What happened to you?" I began to ask her, but then her grip tightened around my waist. She lifted me off the grass and swung me around.

"It's so good to see you!" she sang, dropping me back on my feet.

I stumbled for a moment. I looked at her. Mary-Alice was a foot shorter than me and had the bones of a baby bird. "How are you so strong?" I asked her.

"Oh! Sorry, sorry," said Mary-Alice. She smiled, showing me her wrists. Thick, glittering platinum was wrapped around her forearms. Some foreign language was carved into it, lacing the edges. "It's these armbands. I'm still getting used to them. There's some curse on them that triples my strength, or something. I think those carvings are in ogre blood. Or troll blood. I forget. You won't believe how similar they look."

I took a step back from Mary-Alice, now feeling the cold steel of her breastplate through my clothes. I hadn't noticed until then what she was wearing. Her usual floral dresses and petticoats were gone. Instead she was clad in leather and trimmed in silver. Steel curved over her shoulders and an over-sized sword was strapped to her back.

"Mary-Alice, what in the world?" I asked.

Mary-Alice was oblivious to my reaction. She was still focused on her armbands, flashing them around, pretending she was deflecting bullets with them. "They were a reward from the people in Starkhart. Aren't they awesome? Man, I've got so much to tell you. Is my mum at your house? I haven't got much time."

"Wait, Mary-Alice. What the hell is going on? What are you talking about? Where did you go?” I asked.

Mary-Alice just kept on smiling. "Starkhart," she said, "It's beautiful, Maybel. I need to show you."

"What the hell is Starkhart?'

"It's not a 'what,' it's a 'where' and it's at the other end of the tunnel. Come see." Mary-Alice lifted the vines of ivy. The light at the end of the tunnel was still glowing.

I crossed my arms. "You mean to tell me there's some magical world at the other end of that tunnel?"

"Yes."

"You're insane." 
Mary-Alice laughed. "I can show you if you don't believe me. The portal's still open." She gasped, grabbing my hand. "Oh my gosh, Maybel, you should come with me!"

"Excuse me?"

"Come with me, Maybel. It's amazing. Every day's a new adventure. You'll have a ball. Plus, I'm technically betrothed to a prince I should introduce you to. There was this whole thing with a dragon and apparently rescuing a member of the royal family is a proposal of marriage in Starkhart.”

I pulled my hand away. "Betrothed? You're sixteen!"

"Yeah, don't tell Mum that part. She'll flip. Good thing I didn't rescue his father, huh? The King of Starkhart is nice and everything, but he's super old and really fat. You need to come back with me. I'll introduce you to all my friends."

"Wait, you're going back?" I asked.

Mary-Alice's smile dropped, she looked at her shoes. "Well, yeah. I need to. There's this evil clan of witches destroying everything. I have to help. Plus, I spared the life of that dragon so now it has a blood debt with me. I have a pet dragon now, did I mention that?"

I grabbed Mary-Alice by her wrist. "You're not going anywhere. You're coming back with me."

"But I can't."

"You can and you will. Do you have any idea the hell you've put your mother through? What you've put all of us through?"

"That's why I came back. I only have a few minutes though." MaryAlice reached inside her breast place and pulled out a folded piece of parchment. "I was going to leave this note for someone to find. It explains everything."

"And what does it say? 'Sorry I've disappeared. I'm not murdered, I'm just in Narnia"'

"Starkhart. And I phrased it a little nicer than that, thank you. Look, come back with me so you can understand. The next time the portal opens you can just return."

"Go with you? This close to exams? Are you crazy?"

"Come on. I can teach you how to use a sword."

"When the hell am I going to need to use a sword?"

"Self-defence." 
"Against who? The cops trying to arrest me?"

"Fine, we'll get you a bow and arrow then. Just, come on." MaryAlice placed her palm on my back, pushing me forward. I took two steps with her into the tunnel before I pushed her away and stepped back out.

"No, Mary-Alice. Be realistic for a moment. Please," I said.

Mary-Alice poked her head through the ivy. Her jaw was tight. Behind her, I could see the light inside the tunnel becoming more and more faint. She looked back toward it.

"The portal is closing. I need to go." Mary-Alice looked back toward me. Her face was softer. She pressed the parchment in my hand. "Give this to Mum. Please? I don't want her to worry. Tell her everything."

I shook my head, pushing the parchment back towards her. "They'll think I'm insane. Or that I'm connected to your disappearance. I'll have the cops asking me questions."

"Please, Maybel."

"I can't.' I threw the letter at her feet. "Be realistic. I can't do it. Just come back. We miss you. Please."

I should have known there was no point in trying. Mary-Alice just smiled sadly and disappeared behind the ivy. I stepped into the archway. She was running through the tunnel, her steel boots echoing.

"Come back! Please, Mary! Come back!" I cried out.

I remember this part so well. I remember Mary-Alice growing smaller and smaller while the light at the end of the tunnel flashed like a firework. I remember seeing something in the flash of light. A beautiful kingdom with buildings made from gemstones, a valley of snow-covered mountains surrounding it. A neon red dragon the size of a mini-van was waiting for Mary-Alice, head bowed obediently. I thought it was a trick of the eyes. I blinked and they were gone. The light. The kingdom. The dragon. Mary-Alice. All gone.

I draw a blank after that. Next thing I remember it's dark. Mum found me by the cave entrance. She yelled at me, saying I nearly gave her a heart attack. She didn't seem to notice the tunnel.

Until the day we moved I tried to find Mary-Alice from time to time. Once I got my driver's licence I went back on my own, though as time goes by the tunnel seems harder and harder to find. Today I had to walk around for hours before I found it. Sometimes, I just sit in the open 
archway and talk to her, hoping maybe she can hear me, maybe if I tell her how much I miss her over and over she'll come back. Sometimes I just sit and think about her, like today.

I remember one day when she was visiting. She was nose deep in another fantasy novel.

"I don't know why you waste your time with that fantasy rubbish," I said to her.

She didn't take her eyes off the pages. "We all need a little fantasy from time to time, you know," she said.

"Don’t be stupid," I spat. "Fantasy makes no sense."

Mary-Alice lowered her book. "Fantasy makes perfect sense. It's reality that's confusing."

I just rolled my eyes.

"It is, Maybel. Look at you. You spend all day studying just so you can try to make sense of it, but fantasy helps us understand reality. It keeps us sane."

"It keeps you ignorant and it makes you look stupid," I said.

Outside the lounge room I could hear Mum and Aunt Ruth getting ready to go shopping. Mary-Alice was staring at me. I got up to go with them. I didn't want to fight with her when we were alone. I left her to read the last few chapters of her book.

I stare at the tunnel. I strain my eyes. As the years go by it's getting harder and harder to see it.

Mary-Alice was right. Reality doesn't make any sense. You think things naturally flow in one way, but the next minute it takes a turn and you're back to square one, trying to understand everything again. One minute I was certain that Mary-Alice was dead, missing, most likely murdered. Now I know better. I know Mary-Alice is stuck in another world, living the adventures she always wanted to. I know that she's happy, even if the rest of us aren't.

The day might come where I don't need to find the tunnel to remember that, but for now I do. This is my fantasy. 